\title{
Synthesis and Characterization of Activated Carbon Co-Mixed Electrospun Titanium Oxide Nanofibers as Flow Electrode in Capacitive Deionization
}

\author{
Gbenro Folaranmi, Myriam Tauk, Mikhael Bechelany ${ }^{(D)}$, Philippe Sistat, Marc Cretin *(D) and Francois Zaviska *
}

check for

updates

Citation: Folaranmi, G.; Tauk, M.; Bechelany, M.; Sistat, P.; Cretin, M.; Zaviska, F. Synthesis and

Characterization of Activated Carbon Co-Mixed Electrospun Titanium Oxide Nanofibers as Flow Electrode in Capacitive Deionization. Materials 2021, 14, 6891. https://doi.org/ $10.3390 /$ ma14226891

Academic Editor: Zhenghua Tang

Received: 6 October 2021

Accepted: 9 November 2021

Published: 15 November 2021

Publisher's Note: MDPI stays neutral with regard to jurisdictional claims in published maps and institutional affiliations.

Copyright: (c) 2021 by the authors. Licensee MDPI, Basel, Switzerland. This article is an open access article distributed under the terms and conditions of the Creative Commons Attribution (CC BY) license (https:/ / creativecommons.org/licenses/by/ $4.0 /)$.
Institut Européen des Membranes, IEM, UMR-5635, Université de Montpellier, ENSCM, CNRS, Place Eugène Bataillon, CEDEX 5, 34095 Montpellier, France; gbenro.folaranmi@umontpellier.fr (G.F.); myriam.tauk@umontpellier.fr (M.T.); mikhael.bechelany@umontpellier.fr (M.B.); philippe.sistat@umontpellier.fr (P.S.)

* Correspondence: marc.cretin@umontpellier.fr (M.C.); francois.zaviska@umontpellier.fr (F.Z.)

Abstract: Flow capacitive deionization is a water desalination technique that uses liquid carbonbased electrodes to recover fresh water from brackish or seawater. This is a potential secondgeneration water desalination process, however it is limited by parameters such as feed electrode conductivity, interfacial resistance, viscosity, and so on. In this study, titanium oxide nanofibers $\left(\mathrm{TiO}_{2} \mathrm{NF}\right)$ were manufactured using an electrospinning process and then blended with commercial activated carbon (AC) to create a well distributed flow electrode in this study. Field emission scanning electron microscope (FESEM), X-ray diffraction (XRD), Raman spectroscopy, X-ray photoelectron spectroscopy (XPS), and energy dispersive X-ray (EDX) were used to characterize the morphology, crystal structure, and chemical moieties of the as-synthesized composites. Notably, the flow electrode containing $1 \mathrm{wt} . \% \mathrm{TiO}_{2} \mathrm{NF}\left(\mathrm{ACTiO}_{2} \mathrm{NF} 1 \mathrm{wt} . \%\right)$ had the highest capacitance and the best salt removal rate $\left(0.033 \mathrm{mg} / \mathrm{min} \cdot \mathrm{cm}^{2}\right)$ of all the composites. The improvement in cell performance at this ratio indicates that the nanofibers are uniformly distributed over the electrode's surface, preventing electrode passivation, and nanofiber agglomeration, which could impede ion flow to the electrode's pores. This research suggests that the physical mixture could be used as a flow electrode in capacitive deionization.

Keywords: flow electrode capacitive deionization; electrospinning; activated carbon; desalination

\section{Introduction}

One of the growing challenges of the 21st century is the availability of fresh water. Water contamination because of anthropogenic activities such as industrialization, demographic change, and global warming has resulted in a significant increase in demand for safe drinking water. Water desalination technology could help to alleviate this problem by delivering high quality, pure water. Most desalination technologies, such as multiple effect desalination (MED), reverse osmosis (RO), and others, have high capital costs (when considering plant setup) and energy consumption (when considering pre- and post-treatment of water, as in RO), necessitating the development of a new desalination technique [1].

Capacitive deionization (CDI) is a growing desalination technology attracting attention as an energy-efficient, cost-effective, and ecofriendly water treatment technology. The first and most widely used CDI form involves a pair of porous carbon electrodes separated by a space in which salt water flows as an influent perpendicular to the applied electric field direction [2]. A fundamental variation of this basic CDI form emerged with the unfolding of membrane CDI (MCDI). In this architecture, ion exchange membranes were added to the CDI cell configuration to block co-ions from carrying parasitic current, which improves charge efficiency and can increase the charge storage in the electrodes porous structure [3]. In the past decade, a new class for CDI based on MCDI was developed which introduced 
carbon flow electrodes that can be pumped through the electrode compartments. Flow electrode CDI (FCDI) is a promising second-generation water desalination method based on the principle of ions adsorption. When a specific voltage is applied, it entails using a polarized flow electrode (liquid electrode) travelling via a flow channel to adsorb ions from brackish or seawater via electrical double layer (EDL) formation (interface between electrolyte and electrode) [4].

One of the challenges in FCDI is to improve the conductivity and capacitance of carbon materials used as electrodes, as well as reducing the resistance between the electrode and the electrolyte. This can be accomplished by improving the surface charge of activated carbon for better EDL formation [5].

Because of its beneficial qualities such as high surface area, porosity, availability, and low cost, graphitic carbon, materials such as activated carbon are frequently used as flow electrodes [6,7]. However, for more effective EDL formation and better ion storage, the resistance at the electrode-electrolyte interface should be lowered. As a result, surface modification is required to raise the surface charge of activated carbon.

Metal oxides such as zinc oxide $(\mathrm{ZnO})$, tin oxide $(\mathrm{SnO})$, zirconium oxide $(\mathrm{ZrO})$, and titanium oxide $\left(\mathrm{TiO}_{2}\right)$ have been used to modify carbon in this concept [8,9]. Among all these oxides, $\mathrm{TiO}_{2}$ has a high surface charge that can be used in conjunction with $\mathrm{AC}$ to create new types of electrodes. The aggregation of $\mathrm{TiO}_{2}$ particles, however, is one of the additive's downsides, limiting its performance [10-12]. Small quantities of $\mathrm{TiO}_{2}$ nanofibers are used in activated carbon flow electrodes to alleviate the agglomeration problem since they have a favorable large axial ratio morphology $[13,14]$.

Due to the high resistance of the liquid medium utilized for carbon dispersion for slurry formation, charge transfer resistance is a strong factor hindering the ease of ions diffusion into the pores of carbon electrodes in flow electrodes [15]. As a result, methods for reducing interfacial resistance by adding conducting additives or introducing oxygenated functional groups to activated carbon have been reported in the literature [15-18], but no report on the properties of $\mathrm{TiO}_{2}$ nanofibers in reducing interfacial resistance and their effect on the rheological properties of carbon-based flow electrodes has been found to date.

Nanofiberous materials of high surface area and porosity are considered recently to be used for generating sustainable and green energy resources. Electrospinning method is a low-cost method used to create nanofiberous materials suited for many energy-related applications such as supercapacitors, and Li-ion batteries [19,20].

Motivated by this, we have synthesized $\mathrm{TiO}_{2}$ nanofibers by electrospinning process and mixed it with commercial AC. The proposed electrodes which consisted of different weight percentage of $\mathrm{TiO}_{2} \mathrm{NF}$ were labelled $\mathrm{TiO}_{2} \mathrm{NF}-\mathrm{x}$ where $\mathrm{x}$ represents the weight percentage of $\mathrm{TiO}_{2} \mathrm{NF}$ in the composite $\left(\mathrm{x}=0.5,1.0,1.5,2.0,2.5\right.$, and $\left.5.0 \mathrm{wt} . \% \mathrm{TiO}_{2} \mathrm{NF}\right)$. The electrodes were characterized by FESEM, XRD, Raman spectroscopy, XPS, EDX, and $\mathrm{N}_{2}$ adsorption/desorption. Dynamic viscosity of the mixtures in suspension to build the flow electrodes was also investigated. Hence, the electrochemical properties of the as-prepared flow electrodes ( $\mathrm{AC}$ and $\mathrm{TiO}_{2} \mathrm{NF}-\mathrm{x}$ ) were analyzed by cyclic voltammetry $(\mathrm{CV})$ to determine their capacitance after which the flow electrodes were tested in a laboratory-made FCDI cell for desalination.

\section{Materials and Methods}

\subsection{Materials}

Activated carbon, Darco (CAS no: 7440-44-0, MW $12.01 \mathrm{~g} \mathrm{~mol}^{-1}$ ), titanium (IV) isopropoxide $\left(\mathrm{C}_{12} \mathrm{H}_{28} \mathrm{O}_{4} \mathrm{Ti}\right.$, CAS no: 546-68-9, MW $\left.284.22 \mathrm{~g} \mathrm{~mol}^{-1}, 97 \%\right)$, poly(vinyl pyrrolidone) (PVP, CAS no: 9003-39-8, MW 1,300,000 $\mathrm{g} \mathrm{mol}^{-1}$ ), and sodium chloride (NaCl, CAS no: 7647-14-5, MW $58.44 \mathrm{~g} \mathrm{~mol}^{-1}, 99 \%$ ) were obtained from Sigma Aldrich, Steinheim, Germany. Acetic acid (CH3COOH MW $60.052 \mathrm{~g} \mathrm{~mol}^{-1}, 99.5 \%$ assay), absolute ethanol (C2H5OH MW $46.07 \mathrm{~g} \mathrm{~mol}^{-1}, 99.99 \%$,) were obtained from VWR chemicals, Fontenay-sous Bois, France. Polyvinylidenefluoride (PVDF) (CAS no: 24937-79-9) was obtained from Alfa Aesar, Erlenbachweg 2, Kendel, Germany. All reagents were used without any further 
purification. Cationic and anionic exchange membranes were purchased from Membranes International Inc. (Ringwood, NJ, USA) and Deionized water $(18 \mathrm{M} \Omega \cdot \mathrm{cm})$ was used to prepare standard solutions and suspensions.

\subsubsection{Synthesis of $\mathrm{TiO}_{2}$ Nanofibers by Electrospinning}

The $\mathrm{TiO}_{2}$ nanofibers were synthesized by electrospinning technique. Briefly, solution A containing $3 \mathrm{~mL}$ of ethanol was added to $0.3 \mathrm{~g}$ of polyvinyl pyrrolidone (PVP) and then stirred until dissolution. Then, solution B consisting of $2 \mathrm{~mL}$ ethanol, $2 \mathrm{~mL}$ of acetic acid, and $3 \mathrm{~mL}$ of titanium isopropoxide was stirred for $45 \mathrm{~min}$. This is then followed by the addition of solution B into clear solution of A and then further stirred for $50 \mathrm{~min}$ to obtain a sol gel solution. Electrospinning of the sol-gel solution was carried out at $22.30 \mathrm{kV}$. The distance between the collector and the syringe tip was maintained at $10 \mathrm{~cm}$, and the injection speed was $0.5 \mathrm{~mL} \mathrm{~min}{ }^{-1}$. The obtained electrospun nanofiber materials were sintered in air atmosphere at $400{ }^{\circ} \mathrm{C}$ for $4 \mathrm{~h}$ with a ramp rate of $1^{\circ} \mathrm{C} \mathrm{min}-1$.

\subsubsection{Preparation of $\mathrm{AC}$ and $\mathrm{ACTiO}_{2} \mathrm{NF}-\mathrm{x}$ Flow Electrodes}

For flow electrode preparation, certain amount of powdered commercial $\mathrm{AC}$ and $\mathrm{ACTiO}_{2} \mathrm{NF}-\mathrm{x}$ (in which $\mathrm{x}$ corresponds to $1.0,1.5,2.0,2.5$, and $5.0 \mathrm{wt} . \%$ of $\mathrm{TiO}_{2} \mathrm{NF}$ ) were weighed and dispersed in deionized water as presented in Table 1 . The mixtures were sonicated for $3 \mathrm{~h}$ and stirred for $1 \mathrm{~h}$ before being fed into the cell. The tank containing the slurry electrode was continuously stirred on a magnetic stirrer during the course of the experiment.

Table 1. Composition of flow electrodes.

\begin{tabular}{cccc}
\hline Electrode Material & $\begin{array}{c}\text { FE (10 wt. } \%) \\
(\mathbf{g})\end{array}$ & $\begin{array}{c}\mathbf{D H}_{\mathbf{2}} \mathbf{O} \\
(\mathbf{m L})\end{array}$ & $\begin{array}{c}\mathbf{T i O}_{\mathbf{2}} \mathbf{N F} \\
\mathbf{( g )}\end{array}$ \\
\hline $\mathrm{AC}$ & 7.80 & 70 & 0 \\
$\mathrm{ACTiO}_{2} \mathrm{NF}-0.5$ & 7.76 & 70 & 0.04 \\
$\mathrm{ACTiO}_{2} \mathrm{NF}-1.0$ & 7.72 & 70 & 0.08 \\
$\mathrm{ACTiO}_{2} \mathrm{NF}-1.5$ & 7.68 & 70 & 0.12 \\
$\mathrm{ACTiO}_{2} \mathrm{NF}-2.0$ & 7.64 & 70 & 0.16 \\
$\mathrm{ACTiO}_{2} \mathrm{NF}-2.5$ & 7.60 & 70 & 0.20 \\
$\mathrm{ACTiO}_{2} \mathrm{NF}-5.0$ & 7.40 & 70 & 0.40 \\
\hline
\end{tabular}

Note: FE: Feed electrode; $\mathrm{DH}_{2} \mathrm{O}$ : deionized water.

\subsection{Physical Characterization}

FESEM was used to analyze the morphology of the samples (Hitachi S4800, Tokyo, Japan). The structural properties were studied by using Raman spectroscopy (HORIBA Xplora, Tokyo, Japan) and XRD (Pan Analytical X'pert Phillips, Almelo, The Netherlands). XPS (ESCALAB 250 Thermo Electron, Montigny Le Bretonneux, France) and EDX (X-Max, Oxford, UK) were used to investigate the atomic composition and chemical moieties of the materials. For the XPS analysis, the excitation source was a monochromatic source Al $\mathrm{K} \alpha$ anode with photoenergy that was observed at $1486.6 \mathrm{eV}$. The analyzed surface has a diameter of $500 \mu \mathrm{m}$. The photoelectron spectra were calibrated in terms of bond energy with respect to the energy of the $\mathrm{C}=\mathrm{C}$ component of carbon C1s at $284.4 \mathrm{eV}$. Surface area was obtained by using $\mathrm{N}_{2}$ adsorption/desorption at $77 \mathrm{~K}$ (Micromeritics ASAP, Verneuil en Halatte, France). Dynamic viscosity was measured using Anton Paar Rheometer Physica MCR 301 (Anton Paar, Graz, Austria).

\subsection{Electrochemical Characterizations}

Solid electrodes for electrochemical characterization of pristine $\mathrm{AC}$ and $\mathrm{ACTiO}_{2} \mathrm{NF}$ were made by combining activated carbon powder $(0.32 \mathrm{~g})$, carbon black $(0.04 \mathrm{~g})$, and poly (vinylidene fluoride fluoride PVdF, $0.04 \mathrm{~g}$ ) in $3 \mathrm{~mL} \mathrm{~N}$-Methyl-2-pyrrolidone (NMP). To establish homogeneity, the mixture was agitated for $2 \mathrm{~h}$ and then sonicated for $40 \mathrm{~min}$. 
After that, the slurry was applied on a graphite sheet. The coated electrode was dried in an oven for $1-2 \mathrm{~h}$ at $80^{\circ} \mathrm{C}$. The as-synthesized titanium oxide nanofibers were added $(0.5,1.0$, $1.5,2.0,2.5$, and $5.0 \mathrm{wt} . \%$ ) to AC containing carbon black and PVDF, and the mixture was agitated for several hours in $3 \mathrm{~mL}$ NMP for $\mathrm{ACTiO}_{2} \mathrm{NF}$ synthesis. After that, the mixture was sonicated for $40 \mathrm{~min}$. The slurry was subsequently immobilized by depositing it on a graphite sheet. It was then dried in an oven at $80^{\circ} \mathrm{C}$ for $1-2 \mathrm{~h}$ to produce solid electrodes.

The electrochemical properties of the prepared electrodes were examined by using CV. $\mathrm{CV}$ tests were performed using a three-electrode system. The mixtures were deposited on a graphite sheet as support with an exposed surface area of $1 \mathrm{~cm}^{2}$, while a platinum mesh and a saturated $3 \mathrm{M} \mathrm{KCl}, \mathrm{Ag} / \mathrm{AgCl}$ electrode served as counter and reference electrodes respectively. A molar $\mathrm{NaCl}$ solution was used as electrolyte. Voltammetry measurements were performed with Origalys potentiostat (OGF01A, Origalys Electrochem SAS, Rillieuxla-Pape, France) at an operating window from -0.4 to $0.6 \mathrm{~V}$ vs ref (to ensure electrochemical stability of the electrolyte and prevent water splitting i.e., oxygen and hydrogen evolution) in $1 \mathrm{M} \mathrm{NaCl}$ electrolyte.

The double-layer capacitance was determined using cyclic voltammetry at different scan rates by considering the charging and the discharging currents at $0.1 \mathrm{~V}$ vs. ref. The determined double-layer capacitance of the system was the average of the absolute value of the slope of the linear plot of charging and discharging currents fitted to the data. CDL as the double layer capacitance was determined using Equation (1):

$$
\mathrm{i}=v \mathrm{C}_{\mathrm{DL}} \text {. }
$$

The double-layer charging current density $\mathrm{i}\left(\mathrm{A} \cdot \mathrm{cm}^{-2}\right)$ is equal to the product of the scan rate $v\left(\mathrm{~V} \cdot \mathrm{s}^{-1}\right)$, and the electrochemical double-layer capacitance $\mathrm{C}_{\mathrm{DL}}\left(\mathrm{F} \cdot \mathrm{cm}^{-2}\right)$.

\subsection{FCDI Measurement}

The schematic diagram of the close loop experimental set-up is shown in Figure 1 in which the cell was powered by a potentiostat and the feed solution (FS, $5 \mathrm{~g} \cdot \mathrm{L}^{-1}$ ) was made to pass through a spacer sandwiched in between cation and anion exchange membranes. The feed electrodes (FE) stored in a reservoir (were made to pass (by pumping) through flow channels and as they exit the channels, they are fed back to the reservoir and then re-circulated; this allows co-mixing of opposite charged ions outside the cell. Figure 2 shows the breakdown of the cell components with the current collector $(6 \mathrm{~mm}$ width and $0.9 \mathrm{~mm}$ depth channel), the ions exchanges membranes and spacer $(0.9 \mathrm{~mm}$ thick). The flow rate of the electrodes was operated at $40 \mathrm{~mL} \mathrm{~min}^{-1}$. Each desalination experiment was conducted for $30 \mathrm{~min}$. The initial conductivity of the salt solution and that of the effluent was monitored at room temperature by ion conductivity meter (Hanna Instruments SRL) all along the $30 \mathrm{~min}$ of the experiment. A constant voltage difference of $1.2 \mathrm{~V}$ was applied to the FCDI unit cell using an Origalys potentiostat (OGF01A, Origalys Electrochem SAS) for desalination experiments. The current intensity passing through the FCDI unit cell was consequently measured by the potentiostat during the experiment.

In the present work, the following indicators defined FCDI performances:

Salt removal rate in $\mathrm{mg} \cdot \mathrm{min}^{-1} \cdot \mathrm{cm}^{-2}(\mathrm{SRR})$ relates to the mass of salt adsorbed $(\mathrm{mg})$ per FE-FS contact area $\left(\mathrm{cm}^{2}\right)$ per unit of time (min). It is calculated by Equation (2):

$$
\mathrm{SRR}=\frac{(\mathrm{Co}-\mathrm{Cf}) * \mathrm{~V}}{\mathrm{~A} * \mathrm{t}}
$$

Co and $\mathrm{Cf}$ are the initial and final (at $\mathrm{t}=30 \mathrm{~min})$ concentration $\left(\mathrm{mol} \cdot \mathrm{L}^{-1}\right)$, respectively, $\mathrm{V}$ is the volume of the solution (L), A is the contact area between FE: FS, and $t$ is the charging time.

The salt removal efficiency in \% (SRE) was calculated using Equation (3):

$$
\mathrm{SRE}=\frac{(\mathrm{Co}-\mathrm{Cf})}{\mathrm{Co}} * 100
$$


Charge efficiency (CE) in \% which relates to the ratio of salt adsorbed to the quantity of charge passed into the system was calculated by Equation (4):

$$
\mathrm{CE}=\frac{\mathrm{z}(\mathrm{Co}-\mathrm{Cf}) \mathrm{VF}}{\mathrm{M} \int \mathrm{I} d \mathrm{t}} * 100
$$

where $\mathrm{z}$ is the equivalent charge of the ions, $\mathrm{F}$ is the Faradaic constant, $\mathrm{M}$ is the molar weight, and $\int \mathrm{I} d \mathrm{t}$ is the integrated quantity of charge passed to the system as a function of time. $C E$ is a good indicator for the energy efficiency of the system and will directly affect the operating cost of the system (OPEX).

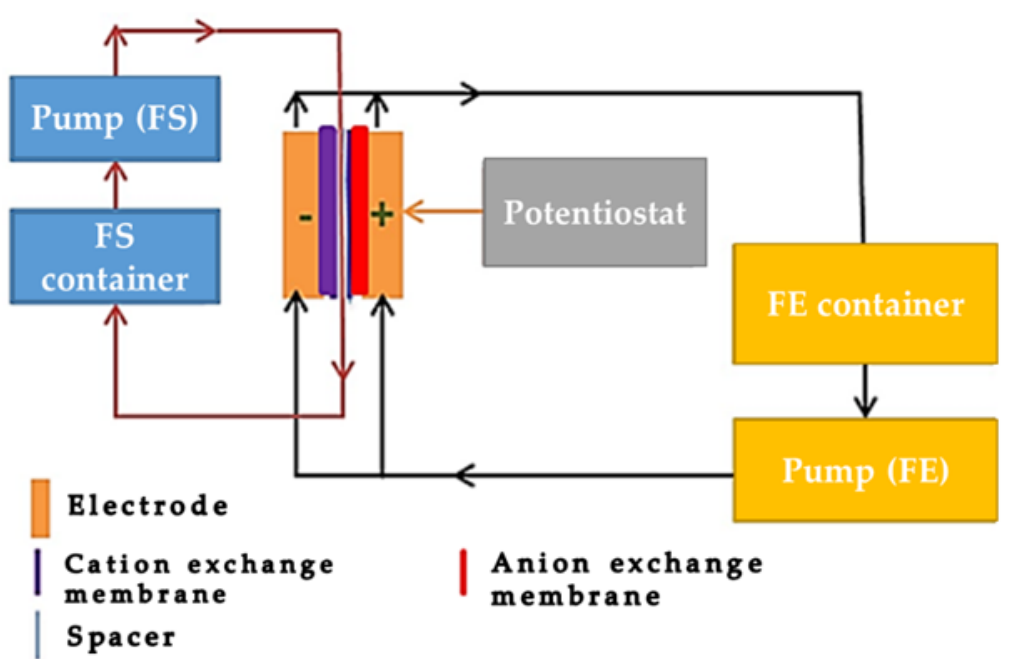

Figure 1. Schematic diagram of FCDI setup is a figure.

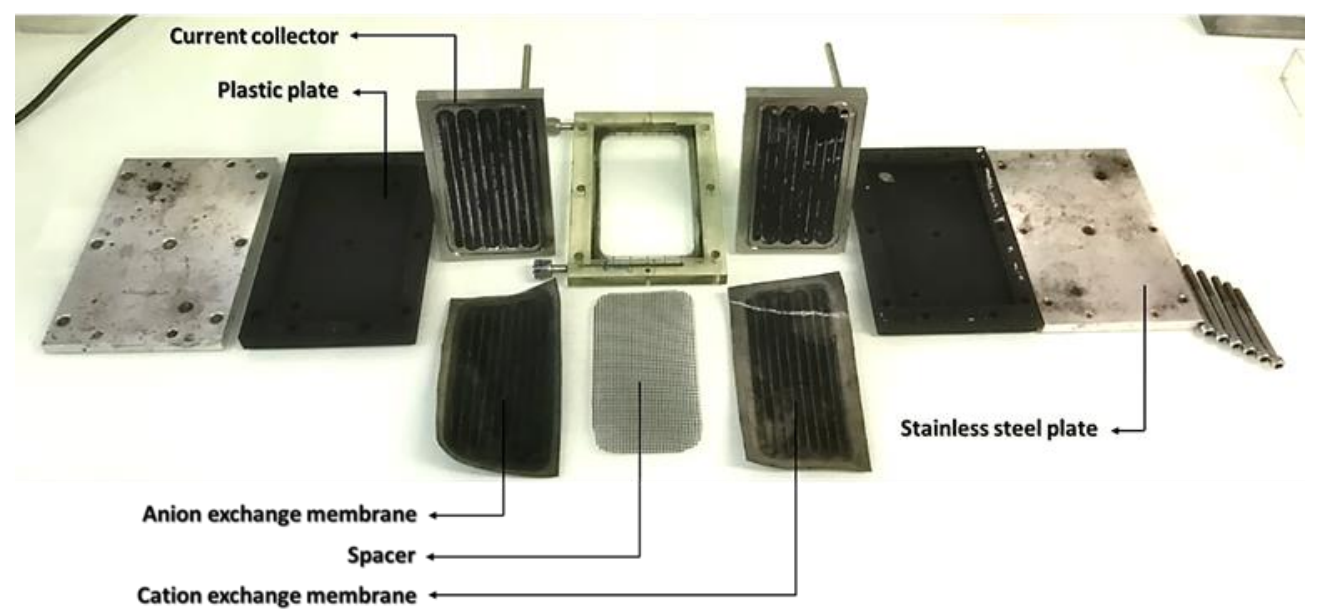

Figure 2. Individual components of FCDI cell.

\section{Results and Discussion}

\subsection{Morphology}

The morphology of as-synthesized titanium oxide nanofibers $\left(\mathrm{TiO}_{2} \mathrm{NF}\right)$, pristine $\mathrm{AC}$, and the $\mathrm{ACTiO}_{2} \mathrm{NF}-x$ electrodes are shown in Figure 3a-h respectively. From Figure 3a, it is apparent that the electrospun $\mathrm{TiO}_{2}$ showed fiber-like morphology with no beads formation. This shows the successful nanofibrous morphology of $\mathrm{TiO}_{2}$ formation by electrospinning process. Figure $3 \mathrm{~b}$ shows the morphology of pristine AC. It is clear that it has no defined shape with rough or uneven surface characteristics while Figure $3 c-h$ reveals the presence of $\mathrm{TiO}_{2} \mathrm{NF}$ on the surface of $\mathrm{AC}$, indicating that the additive was successfully introduced by co-mixing. 

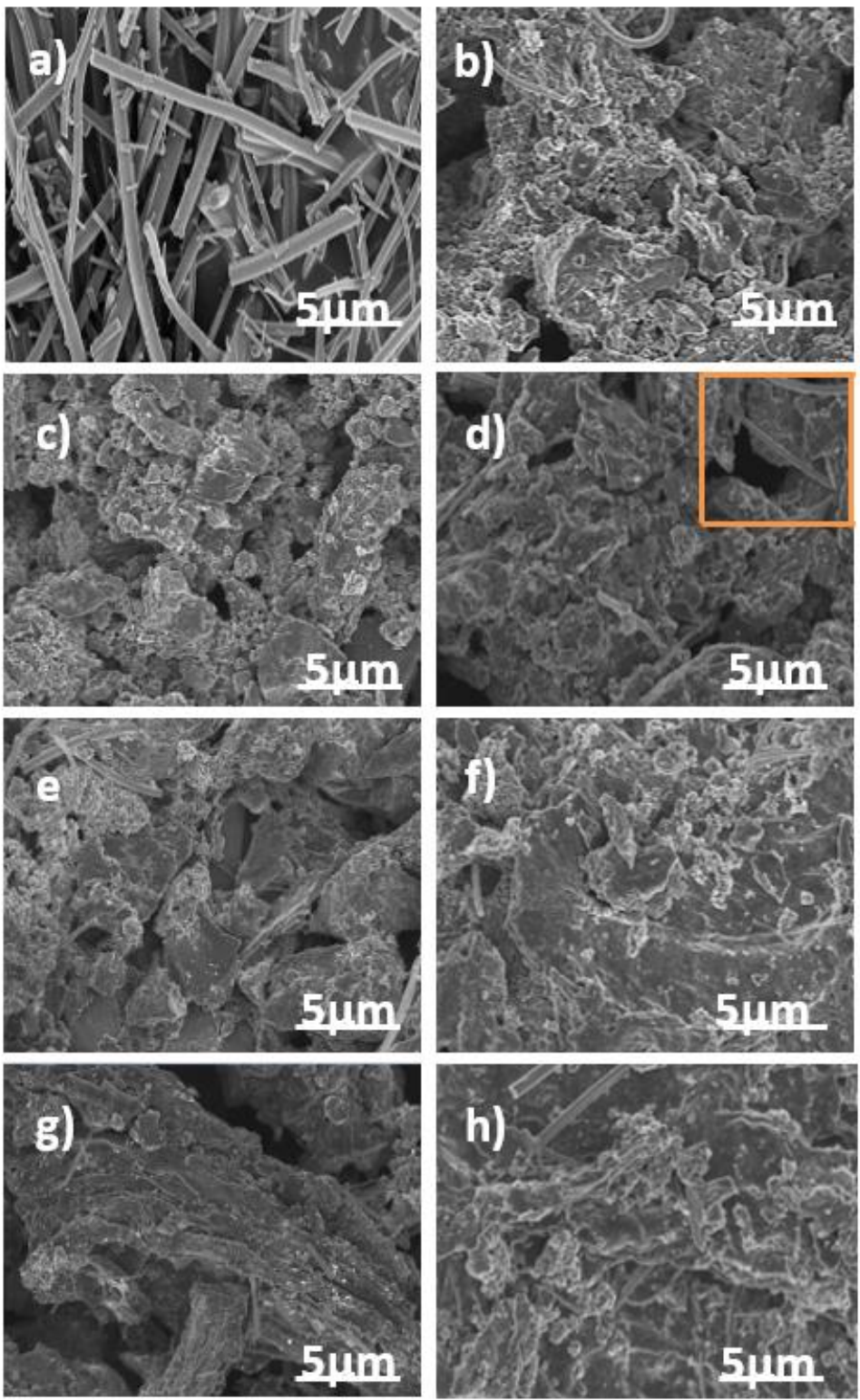

Figure 3. FESEM top view images of (a) $\mathrm{TiO}_{2} \mathrm{NF}(\mathbf{b}) \mathrm{AC}(\mathbf{c}-\mathbf{h}) \mathrm{ACTiO}_{2} \mathrm{NF}-\mathrm{x}$, where $(\mathrm{x}=0.5,1.0,1.5$, 2.0, 2.5 and 5.0 wt. $\% \mathrm{TiO}_{2} \mathrm{NF}$ ) respectively.

\subsection{Structural Properties}

Figure $4 a, b$ shows the Raman spectra and diffractogram of the $\mathrm{TiO}_{2} \mathrm{NF}$, pristine $\mathrm{AC}$ and $\mathrm{ACTiO}_{2} \mathrm{NF}$ s respectively. The Raman spectrum of the pristine $\mathrm{AC}$ and $\mathrm{ACTiO}_{2} \mathrm{NF}$ in Figure 4a conforms to a typical graphitic carbon with distinguishable peaks at $1350 \mathrm{~cm}^{-1}$ and $1590-1610 \mathrm{~cm}^{-1}$ corresponding to D and G bands respectively [21]. D band arises from a defect that is based on out of plane vibration while $G$ band relates to the ordered structure of graphite crystals [13]. For the as-synthesized $\mathrm{TiO}_{2} \mathrm{NF}$, Figure $4 \mathrm{a}$, major peaks are observed at $142,388,516$, and $638 \mathrm{~cm}^{-1}$ indicating anatase phase characteristics [8]. Distinguishable peaks of $\mathrm{TiO}_{2} \mathrm{NF}$ were observed in some of the composites especially for those with high percentage of $\mathrm{TiO}_{2} \mathrm{NF}$ as shown in Figure 4a. This indicates the successful mixing of the nanofibers with the AC.

Structural investigation was carried out to understand the crystalline nature of the materials. Figure $4 \mathrm{~b}$ shows the diffractogram of pure $\mathrm{TiO}_{2} \mathrm{NF}$, pristine $\mathrm{AC}$, and its composites. The $\mathrm{TiO}_{2} \mathrm{NF}$ crystals are predominantly dominated with definite and sharp diffraction peaks at $2 \theta=25^{\circ}, 39^{\circ}$ and $43.5^{\circ}$ relating to 101,004 , and 200 planes of anatase phase respectively with the presence of rutile phase at $2 \theta=27.5^{\circ}, 36^{\circ}$, and $41^{\circ}$ relating to 110,101 , and 
111 planes respectively [8]. Typical diffraction peaks of all graphite material is observed for pristine $\mathrm{AC}$ and $\mathrm{ACTiO}_{2} \mathrm{NF}$ at $2 \theta=26^{\circ}$ and $43.5^{\circ}$ corresponding to 002 and 100 or 101 planes of graphite respectively. The sharp diffraction peaks observed at 002 planes indicates the presence of graphite microcrystalline structure in the AC [13]. In comparison with pristine $\mathrm{AC}$, peaks of $\mathrm{TiO}_{2} \mathrm{NF}$ were detected at $25^{\circ}, 27.5^{\circ}$, and $48^{\circ}$ diffraction peaks of $\mathrm{TiO}_{2} \mathrm{NF}$ in all the composites thus showing successful doping of the nanofibers in the AC. Furthermore, using Debye-Scherrer equation, $(D=K \lambda / \beta, \cos \theta)$ where $K$ is the constant value of $0.9, \lambda$ is the radiation of the XRD machine $(0.1541 \mathrm{~nm}), \beta$ is the full width at half maximum of the diffraction peak in radian, and $\theta$ is the diffraction angle in radian, no changes were observed in the crystallite size $(10 \pm 0.830 \mathrm{~nm})$ of the as-synthesized $\mathrm{TiO}_{2}$ nanofibers and $\mathrm{ACTiO}_{2} \mathrm{NF}$.

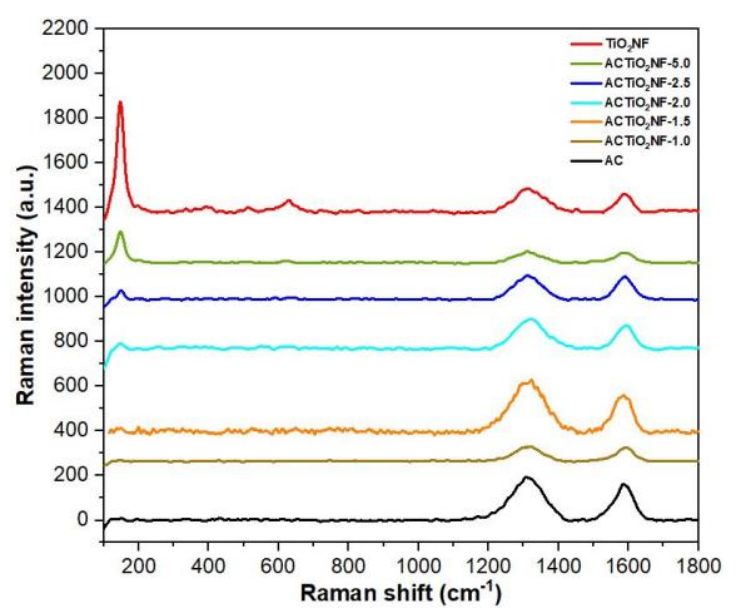

(a)

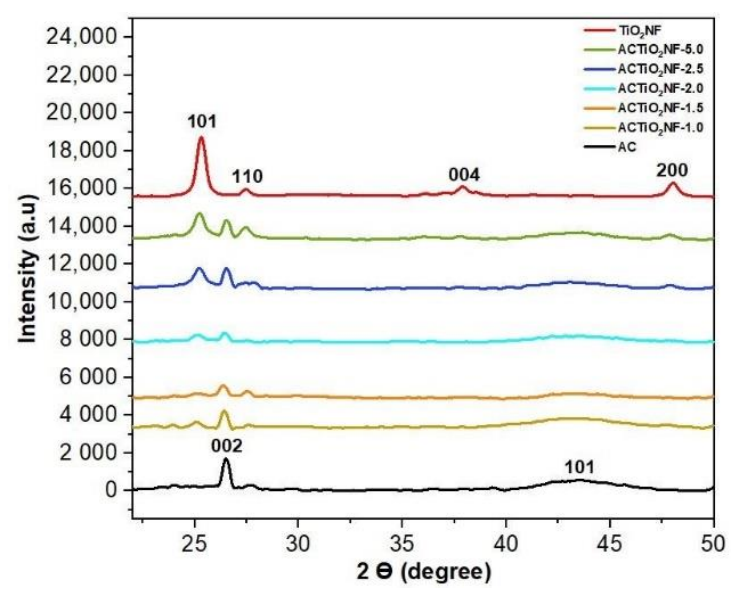

(b)

Figure 4. (a) Raman spectra of Titanium oxide nanofibers $\mathrm{TiO}_{2} \mathrm{NF}$, pristine $\mathrm{AC}$, and its composites $\left(\mathrm{ACTiO} \mathrm{NF}_{2} \mathrm{~N}\right)$ and (b) diffractograms of titanium oxide nanofibers $\left(\mathrm{TiO}_{2} \mathrm{NF}\right)$, pristine $\mathrm{AC}$ and its composites $\left(\mathrm{ACTiO}_{2} \mathrm{NF}-\mathrm{x}\right.$ where $\mathrm{x}=0.5,1.0$, $1.5,2.0,2.5$, and 5.0 wt. $\left.\% \mathrm{TiO}_{2} \mathrm{NF}\right)$.

\subsection{EDX and XPS Studies}

Figure $5 \mathrm{a}, \mathrm{b}$ shows the EDX spectra that were obtained in order to identify the composition of the pristine AC and the composite electrode. Evidently from EDX, the elements detected at highest percentage in our materials are $\mathrm{C}$ and $\mathrm{O}$. Titanium was detected among other elements in little quantity in the composite as shown in Figure $5 \mathrm{~b}$. The presence of fluorine was also detected due to the addition of PVDF (binder) added during electrode fabrication. Moreover, EDX mapping was further used to investigate the distribution of the additive in the mixture. From Figure S1a,b it can be seen that the additive distribution at lower concentration ( $1 \mathrm{wt} . \%)$ is homogenous (even dispersion) while at higher concentration (5 wt.\%), its distribution is concentrated within a particular region. The results confirm the formation of well-dispersed nanofibrous within the carbon structure at low percentage concentration.

Further investigation was carried out using XPS in order to verify any change in the chemical composition of the pristine $\mathrm{AC}$ and its composites. Figure $5 \mathrm{c}$ shows two prominent peaks at 458.69 and $464.44 \mathrm{eV}$ belonging to Ti $2 \mathrm{P}_{3 / 2}$ and Ti $2 \mathrm{P}_{1 / 2}$ respectively [22,23]. From Figure $5 c$, it is shown that Ti (IV) is present in normal state in the composites due to the observed spin orbital splitting corresponding to $5.76 \mathrm{eV}$ that is obtained between $\mathrm{Ti} 2 \mathrm{P}_{1 / 2}$ and Ti $2 \mathrm{P}_{3 / 2}$. [23]. As shown in Figure 5d, no titanium was detected in the XPS spectra survey scan of the pristine $\mathrm{AC}$ on comparison with $\mathrm{ACTiO}_{2} \mathrm{NF}$; a complementary result with that of EDX. The O1s peak in the composite increased a little bit when compared to pristine AC due to the influence of oxygen content of the additive. According to XPS, the 
atomic composition of the $\mathrm{ACTiO}_{2} \mathrm{NF}-1.0$ consisted of $\mathrm{C} 1 \mathrm{~s} 90.6 \pm 0.11 \%, \mathrm{O} 1 \mathrm{~s} 7.9 \pm 0.12 \%$, and Ti 2 p $1.0 \pm 33.33 \%$ while that of pristine AC is $\mathrm{C} 1 \mathrm{~s} 94 \pm 0.84 \%$ and $\mathrm{O} 1 \mathrm{~s} 5 \pm 3.84 \%$.

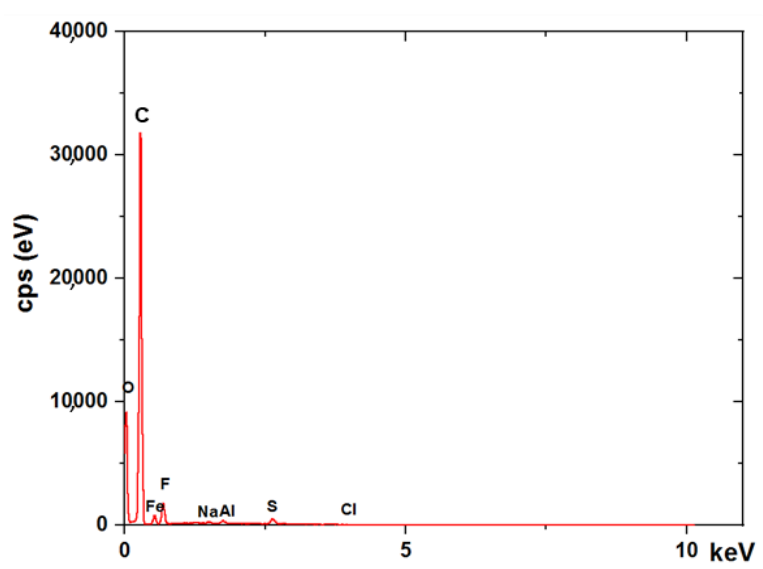

(a)

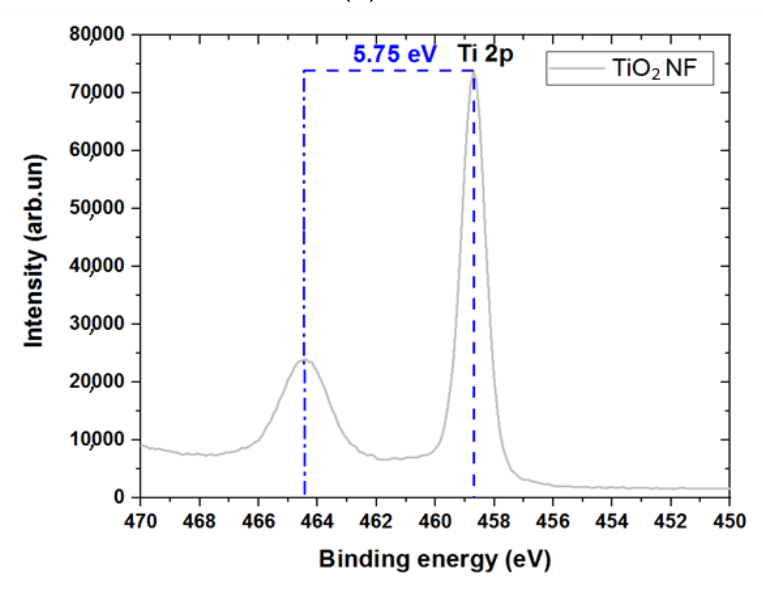

(c)

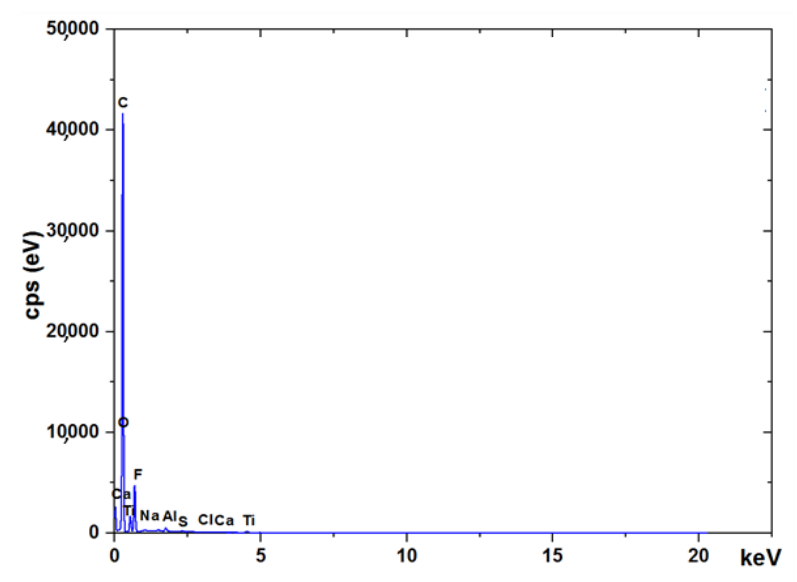

(b)

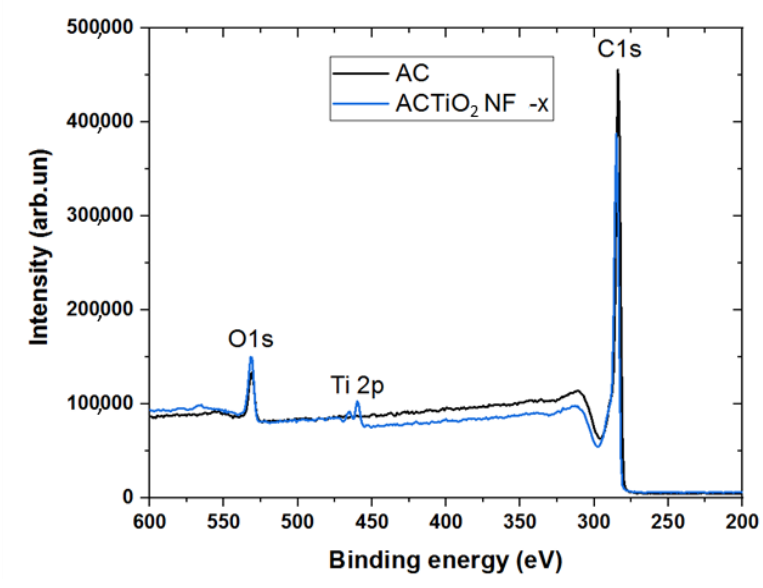

(d)

Figure 5. EDX spectra of (a) pristine $\mathrm{AC}(\mathbf{b}) \mathrm{ACTiO}_{2} \mathrm{NF}-\mathrm{x}$ and XPS spectra of (c) $\mathrm{Ti} 2 \mathrm{p}$ for $\mathrm{TiO}_{2} \mathrm{NF}$ (d) the composite pristine $\mathrm{AC}$ and $\mathrm{ACTiO}_{2} \mathrm{NF}$ where $\mathrm{x}=1.0$ wt. $\% \mathrm{TiO}_{2} \mathrm{NF}$.

\subsection{Rheology Study}

Rheology property reveals the flow nature of the slurry used under applied force. The viscosity nature of the slurry electrode was measured as a function of shear rate. Here, rheology property is in terms of dynamic viscosity, which is used to describe resistance to flow of liquid while shear rate describes the speed of deformation of the slurry under applied force. The dynamic viscosity was determined at a constant concentration of $10 \mathrm{wt} . \%$ carbon content in the slurry. From Figure 6a, it is obvious that the slurry follows a nonNewtonian fluid (shear thinning effect) in which the viscosity of the slurries decreases with increasing shear rate. To understand the effect of the additive, the viscosities of both pristine $\mathrm{AC}$ and the $\mathrm{ACTiO}_{2} \mathrm{NF}$ mixture were measured and compared as shown in Figure 6a. It is obvious from the rheogram curves that viscosity increases as the additive content increases in the composite. However, at low percentage of additive, there seems to be no significant difference in the viscosities of both the pristine $\mathrm{AC}$ and the $\mathrm{ACTiO}_{2} \mathrm{NF}$ mixture but at i.e., $\mathrm{TiO}_{2} \mathrm{NF} \geq 2.0 \mathrm{wt}$.\%, a sharp increase in viscosity was observed. The increase in viscosity can be attributed to the high specific surface area (increase frictions) of titanium nanofibers as well as its surface charge. The surface charge of the nanofibers (whether positive or negative) leads to creation of repulsive forces existing within the nanoparticles and as a result, they tend to move further apart due to strengthened force 
of repulsion; consequently, viscosity increases with increasing repulsive forces [24-28]. Therefore, as the concentration of the additive in the electrodes increases, a distinguishable jump in their viscosity was observed due to increase in force of repulsion as shown in Figure $6 \mathrm{~b}$. This implies that the presence of additive at high content level could lead to potential clogging of the feed electrodes in the cell.

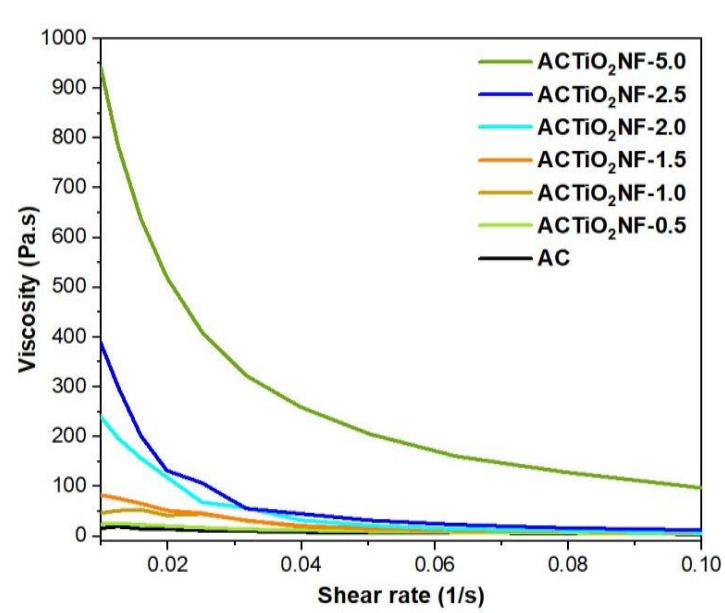

(a)

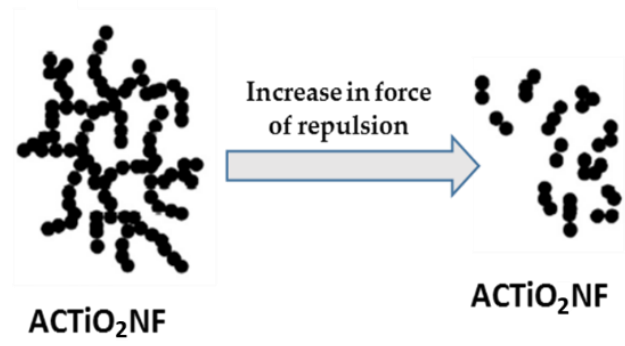

(b)

Figure 6. (a) Rheological properties of the flow-electrodes. (b) Schematic diagram of the $\mathrm{ACTiO}_{2} \mathrm{NF}_{\text {mixture behavior under }}$ repulsive forces.

\subsection{Electrochemical Properties}

Electrochemical behavior of the pristine $\mathrm{AC}$ electrode and $\mathrm{ACTiO}_{2} \mathrm{NF}$ electrodes were carried out using CV at different scan rates in a potential window from -0.4 to $0.6 \mathrm{~V}$ vs. Ref (to ensure electrochemical stability of the electrolyte and prevent water splitting i.e., oxygen and hydrogen evolution). The experiment was conducted in $1 \mathrm{M} \mathrm{NaCl}$ aqueous solution to investigate the influence of the additive at different ratios. $\mathrm{CV}$ is an important technique to probe the capacitive nature of EDL $[29,30]$.

Based on the cyclic voltammetry cycles, the EDL capacitance of the electrodes was calculated [31] and is shown in Figure 7.

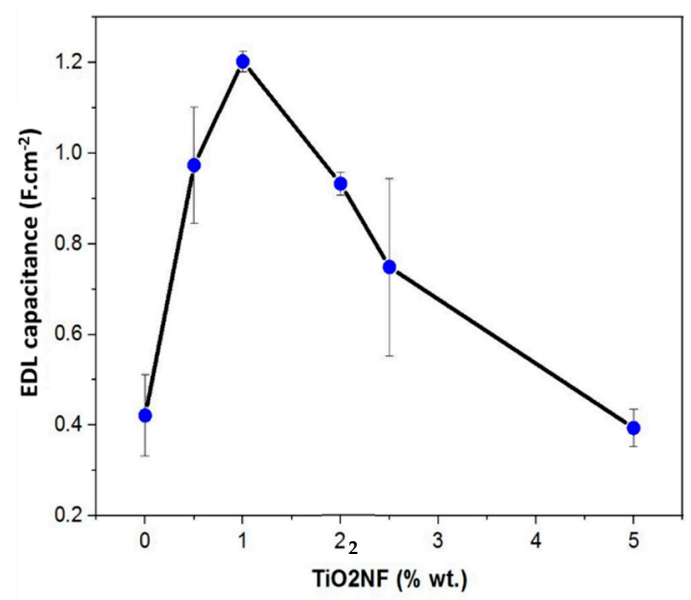

Figure 7. Electrical double-layer capacitance of the system for $\mathrm{AC}$ and $\mathrm{ACTiO}_{2} \mathrm{NF}-\mathrm{x}$ composite electrodes $\left(\mathrm{ACTiO}_{2} \mathrm{NF}-\mathrm{x}\right.$ where $\mathrm{x}=0.5,1.0,2.0,2.5$, and $\left.5.0 \mathrm{wt} . \% \mathrm{TiO}_{2} \mathrm{NF}\right)$.

Thus, incorporating $\mathrm{TiO}_{2} \mathrm{NF}$ at low rate into our carbon material enhances its double layer capacitance due to the formation of a uniform network distribution of $\mathrm{TiO}_{2}$ nanofibers between AC particles. However, as the presence of $\mathrm{TiO}_{2} \mathrm{NF}$ increases in the 
composite, there seem to be exhibition of poor electrochemical behavior possibly due to the increase in resistance to easy flow of ions into the pores of the electrode because of $\mathrm{TiO}_{2} \mathrm{NF}$ agglomeration [14]. Our results correlate to the findings reported in literature [8,14].

\subsection{Desalination Performance}

As reported in literature, the electrosorption performance of carbon-based materials is linked to their capacitive properties amid other factors $[9,29]$. As explained earlier, $\mathrm{TiO}_{2} \mathrm{NF}$ was added at different wt.\% to influence the capacitance of commercial AC and this factor was verified through the electrochemical characteristics of the electrodes. Furthermore, in order to confirm the link between electrosorption performances and capacitive properties, desalination experiments were carried out under a semi-continuous system in a flow channel. Desalination was conducted at an operational cell potential $\Delta \mathrm{E}=1.2 \mathrm{~V}$ for $30 \mathrm{~min}$ using $5000 \mathrm{mg} \cdot \mathrm{L}^{-1} \mathrm{NaCl}$ as the feed solution. Difference in conductivity was monitored and recorded during the experiment. FCDI performance indicators such as desalination efficiency (DE) in Figure 8a, salt removal rate (SRR), and charge efficiency (CE) in Figure 8b were used to evaluate the performance of the flow electrodes.

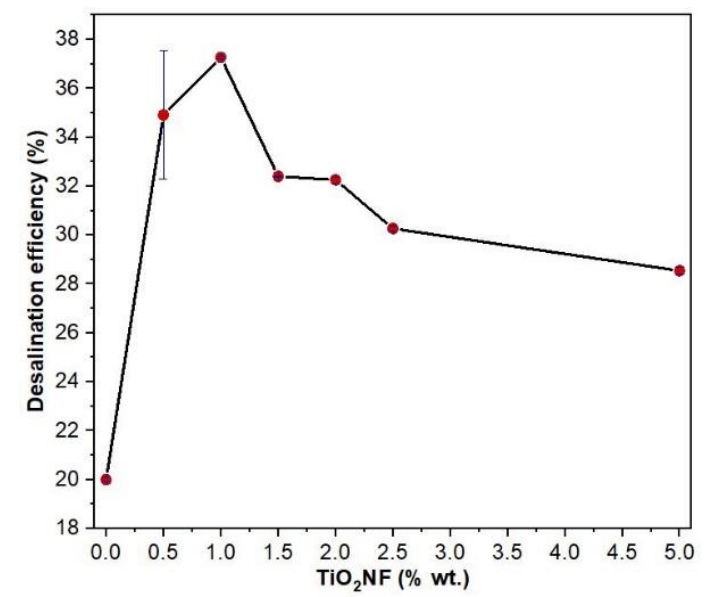

(a)

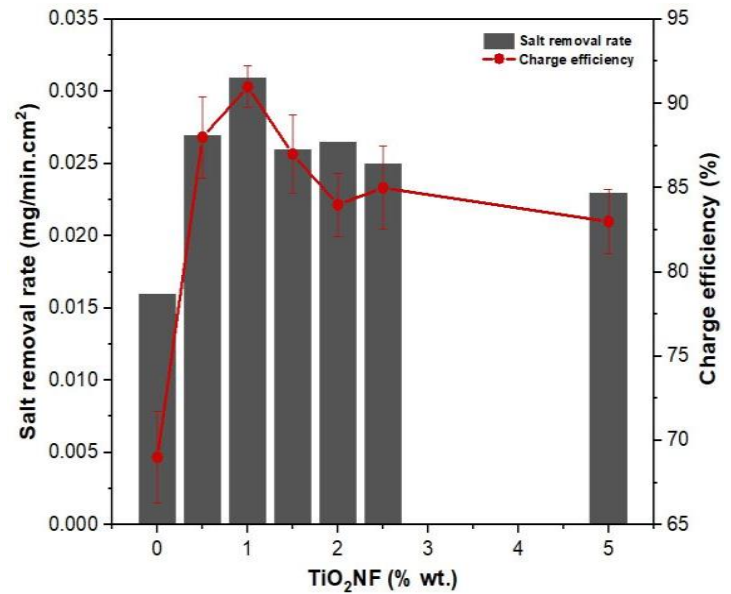

(b)

Figure 8. (a) Desalination efficiency; (b) salt removal rate and charge efficiency of $\mathrm{AC}$ and $\mathrm{ACTiO}_{2} \mathrm{NF}-\mathrm{x}, \mathrm{where}(\mathrm{x}=0.5,1.0$, $1.5,2.0,2.5$, and $5.0 \mathrm{wt} . \% \mathrm{TiO}_{2} \mathrm{NF}$ ) respectively.

Important increase in DE is noticed in Figure 8a. Notably, the $\mathrm{ACTiO}_{2} \mathrm{NF}$ electrodes show higher DE than pristine $\mathrm{AC}$ and among all the electrodes, $\mathrm{ACTiO}_{2} \mathrm{NF}-1.0$ exhibited the best DE, which implies fast ion mobility to the pores of the flow electrode thus leading to quick salt removal; a consequent effect on CE and SRR.

Low desalination behavior of $\mathrm{ACTiO}_{2} \mathrm{NF}-\mathrm{x}\left(\mathrm{x} \geq 2.0 \mathrm{wt} . \% \mathrm{TiO}_{2} \mathrm{NF}\right)$ at high percentage could be due to the fact that at this ratio, the nanofibers tend to agglomerate among themselves (not well dispersed or less uniform) and as such, making the pores of the electrode (surface hindrance) not easily accessible for ions adsorption. In addition, electrode passivation is likely to occur due to the high presence of the nanofibers [32]. This will make the electrode surface not easily permeable for ions (impermeable layer formation on electrode surface) thus significantly affecting the electrosorption performance of the electrodes as observed in our materials, (whitish layers on the surface of flow electrodes). It has to be mentioned that only a small fraction of titanium nanofiber ( $\leq 1 \%$ weight) is sufficient to significantly increase FCDI performances without increasing much viscosity.

\section{Conclusions}

To summarize, we used an electrospinning procedure to create titanium nanofibers. Without any further post-treatment, the as-spun nanofibers were rationally mixed with AC using a simple agitating procedure to generate hybrid composites of $\mathrm{ACTiO}_{2} \mathrm{NF}-\mathrm{x}(\mathrm{x}=0.5$, 
$1.0,1.5,2.0,2.5$, and $\left.5.0 \mathrm{wt} . \% \mathrm{ACTiO}_{2} \mathrm{NF}\right)$. The composites were subsequently described and tested for the first time as electrodes in FCDI. Introduction of $\mathrm{TiO}_{2}$ nanofibers into AC improved the electrochemical characteristics of the material. The addition of $\mathrm{TiO}_{2}$ nanofibers to the composite electrodes increased their performance, with $\mathrm{ACTiO}_{2} \mathrm{NF}-$ 1.0 demonstrating distinguishing and remarkable properties with the best desalination behavior. The composites' nanofibrous shape allows for greater anchoring within the AC network, allowing for improved ion transport and migration to the pores. Finally, the technology described has the potential to produce carbon-based flow electrodes with better shape and desalination performance in the FCDI methodology.

Supplementary Materials: The following are available online at https://www.mdpi.com/article/10 $.3390 /$ ma14226891/s1. Figure S1: EDX mapping of (a) $\mathrm{ACTiO}_{2} \mathrm{NF}-5.0$ and (b) $\mathrm{ACTiO}_{2} \mathrm{NF}-1.0$.

Author Contributions: Conceptualization, G.F.; methodology, G.F. and M.B.; software, G.F. and M.T.; validation, M.B., F.Z., P.S. and M.C.; investigation, G.F.; resources, F.Z., M.B., P.S. and M.C.; data curation, G.F. and M.T.; writing—original draft preparation, G.F. and M.T.; writing—review and editing, G.F., M.T., F.Z., M.B. and M.C.; visualization, G.F., M.T., F.Z. and M.B.; supervision, M.B., F.Z., P.S. and M.C.; project administration, M.B., F.Z. and M.C. All authors have read and agreed to the published version of the manuscript.

Funding: This research was funded by "Axe $\mathrm{H}_{2} \mathrm{O}$ " and "Axe Energie" in European Institute of Membranes (IEM). And the Federal Government of Nigeria through Tertiary Education Trust fund (TETFUND) and Campus France (CF) for the Ph.D. funding of Gbenro Folaranmi with the funding number CAMPUS FRANCE $914886 \mathrm{H}$.

Data Availability Statement: The data presented in this study are available on request from the corresponding authors.

Acknowledgments: Special thanks to Fida Tanos (IEM) for guidance in titanium nanofibers synthesis and Mahmoud Abid (IEM) for furnace operation.

Conflicts of Interest: The authors declare no conflict of interest.

\section{References}

1. Folaranmi, G.; Bechelany, M.; Sistat, P.; Cretin, M.; Zaviska, F. Towards Electrochemical Water Desalination Techniques: A Review on Capacitive Deionization, Membrane Capacitive Deionization and Flow Capacitive Deionization. Membranes 2020, $10,96$. [CrossRef]

2. Ahmed, M.A.; Tewari, S. Capacitive deionization: Processes, materials and state of the technology. J. Electroanal. Chem. 2018, 813, 178-192. [CrossRef]

3. Biesheuvel, P.M.; van der Wal, A. Membrane capacitive deionization. J. Membr. Sci. 2010, 346, 256-262. [CrossRef]

4. Zhang, C.; Ma, J.; Wu, L.; Sun, J.; Wang, L.; Li, T.; Waite, T.D. Flow Electrode Capacitive Deionization (FCDI): Recent Developments, Environmental Applications, and Future Perspectives. Environ. Sci. Technol. 2021, 55, 4243-4267. [CrossRef]

5. Qu, D. Studies of the activated carbons used in double-layer supercapacitors. J. Power Sources 2002, 109, 403-411. [CrossRef]

6. Porada, S.; Zhao, R.; van der Wal, A.; Presser, V.; Biesheuvel, P.M. Review on the science and technology of water desalination by capacitive deionization. Prog. Mater. Sci. 2013, 58, 1388-1442. [CrossRef]

7. Zou, L.; Li, L.; Song, H.; Morris, G. Using mesoporous carbon electrodes for brackish water desalination. Water Res. 2008, 42, 2340-2348. [CrossRef] [PubMed]

8. Yasin, A.S.; Mohamed, I.M.A.; Mousa, H.M.; Park, C.H.; Kim, C.S. Facile synthesis of $\mathrm{TiO}_{2} / \mathrm{ZrO}_{2}$ nanofibers/nitrogen co-doped activated carbon to enhance the desalination and bacterial inactivation via capacitive deionization. Sci. Rep. 2018, 8, 541. [CrossRef]

9. $\quad$ El-Deen, A.G.; Boom, R.M.; Kim, H.Y.; Duan, H.; Chan-Park, M.B.; Choi, J.-H. Flexible 3D Nanoporous Graphene for Desalination and Bio-decontamination of Brackish Water via Asymmetric Capacitive Deionization. ACS Appl. Mater. Interfaces 2016, 8 , 25313-25325. [CrossRef]

10. Ao, Y.; Xu, J.; Fu, D.; Shen, X.; Yuan, C. Low temperature preparation of anatase $\mathrm{TiO}_{2}$-activated carbon composite film. Appl. Surf. Sci. 2008, 254, 4001-4006. [CrossRef]

11. Ao, Y.; Xu, J.; Fu, D.; Yuan, C. A simple route for the preparation of anatase titania-coated magnetic porous carbons with enhanced photocatalytic activity. Carbon 2008, 46, 596-603. [CrossRef]

12. Xing, B.; Shi, C.; Zhang, C.; Yi, G.; Chen, L.; Guo, H.; Huang, G.; Cao, J. Preparation of TiO2 / Activated Carbon Composites for Photocatalytic Degradation of RhB under UV Light Irradiation. J. Nanomater. 2016, 2016, e8393648. [CrossRef] 
13. Mohamed, I.M.A.; Dao, V.-D.; Barakat, N.A.M.; Yasin, A.S.; Yousef, A.; Choi, H.-S. Efficiency enhancement of dye-sensitized solar cells by use of $\mathrm{ZrO}_{2}$-doped $\mathrm{TiO}_{2}$ nanofibers photoanode. J. Colloid. Interface Sci. 2016, 476, 9-19. [CrossRef] [PubMed]

14. El-Deen, A.G.; Choi, J.-H.; Khalil, K.A.; Almajid, A.A.; Barakat, N.A.M. A TiO 2 nanofiber/activated carbon composite as a novel effective electrode material for capacitive deionization of brackish water. RSC Adv. 2014, 4, 64634-64642. [CrossRef]

15. Park, H.; Choi, J.; Yang, S.; Kwak, S.J.; Jeon, S.; Han, M.H.; Kim, D.K. Surface-modified spherical activated carbon for high carbon loading and its desalting performance in flow-electrode capacitive deionization. RSC Adv. 2016, 6, 69720-69727. [CrossRef]

16. Yang, S.; Choi, J.; Yeo, J.; Jeon, S.; Park, H.; Kim, D.K. Flow-Electrode Capacitive Deionization Using an Aqueous Electrolyte with a High Salt Concentration. Environ. Sci. Technol. 2016, 50, 5892-5899. [CrossRef]

17. Cho, Y.; Yoo, C.-Y.; Lee, S.W.; Yoon, H.; Lee, K.S.; Yang, S.; Kim, D.K. Flow-electrode capacitive deionization with highly enhanced salt removal performance utilizing high-aspect ratio functionalized carbon nanotubes. Water Res. 2019, 151, 252-259. [CrossRef]

18. Liang, P.; Sun, X.; Bian, Y.; Zhang, H.; Yang, X.; Jiang, Y.; Liu, P.-P. Optimized desalination performance of high voltage flow-electrode capacitive deionization by adding carbon black in flow-electrode. Desalination 2017, 420, 63-69. [CrossRef]

19. Martin, C.R. Nanomaterials: A Membrane-Based Synthetic Approach. Science 1994, 266, 1961-1966. [CrossRef]

20. Kiehl, J.T.; Trenberth, K.E. Earth's Annual Global Mean Energy Budget. Bull. Am. Meteor. Soc. 1997, 78, 197-208. [CrossRef]

21. Pant, B.; Park, M.; Park, S.-J. TiO 2 NPs Assembled into a Carbon Nanofiber Composite Electrode by a One-Step Electrospinning Process for Supercapacitor Applications. Polymers 2019, 11, 899. [CrossRef] [PubMed]

22. Xiang, Q.; Yu, J.; Jaroniec, M. Nitrogen and sulfur co-doped $\mathrm{TiO}_{2}$ nanosheets with exposed $\{001\}$ facets: Synthesis, characterization and visible-light photocatalytic activity. Phys. Chem. Chem. Phys. 2011, 13, 4853-4861. [CrossRef] [PubMed]

23. Wang, C.; Shao, C.; Zhang, X.; Liu, Y. $\mathrm{SnO}_{2}$ Nanostructures- $\mathrm{TiO}_{2}$ Nanofibers Heterostructures: Controlled Fabrication and High Photocatalytic Properties. Inorg. Chem. 2009, 48, 7261-7268. [CrossRef]

24. Sizochenko, N.; Syzochenko, M.; Gajewicz, A.; Leszczynski, J.; Puzyn, T. Predicting Physical Properties of Nanofluids by Computational Modeling. J. Phys. Chem. C 2017, 121, 1910-1917. [CrossRef]

25. Yu, F.; Chen, Y.; Liang, X.; Xu, J.; Lee, C.; Liang, Q.; Tao, P.; Deng, T. Dispersion stability of thermal nanofluids. Prog. Nat. Sci. Mater. Int. 2017, 27, 531-542. [CrossRef]

26. Kaggwa, A.; Carson, J.K.; Atkins, M.; Walmsley, M. The effect of surfactants on viscosity and stability of activated carbon, alumina and copper oxide nanofluids. Mater. Today Proc. 2019, 18, 510-519. [CrossRef]

27. Kriegseis, S.; Vogl, A.Y.; Aretz, L.; Tonnesen, T.; Telle, R. Zeta potential and long-term stability correlation of carbon-based suspensions for material jetting. Open Ceram. 2020, 4, 100037. [CrossRef]

28. Hill, A.; Carrington, S. Understanding the links between rheology and particle parameters. Am. Lab. News 2010, 93, 199-203.

29. Folaranmi, G.; Bechelany, M.; Sistat, P.; Cretin, M.; Zaviska, F. Comparative Investigation of Activated Carbon Electrode and a Novel Activated Carbon/Graphene Oxide Composite Electrode for an Enhanced Capacitive Deionization. Materials 2020, 13, 5185. [CrossRef]

30. Hatzell, K.B.; Hatzell, M.C.; Cook, K.M.; Boota, M.; Housel, G.M.; McBride, A.; Kumbur, E.C.; Gogotsi, Y. Effect of Oxidation of Carbon Material on Suspension Electrodes for Flow Electrode Capacitive Deionization. Environ. Sci. Technol. 2015, 49, 3040-3047. [CrossRef]

31. Suryanto, B.H.R.; Chen, S.; Duan, J.; Zhao, C. Hydrothermally Driven Transformation of Oxygen Functional Groups at Multiwall Carbon Nanotubes for Improved Electrocatalytic Applications. ACS Appl. Mater. Interfaces 2016, 8, 35513-35522. [CrossRef] [PubMed]

32. Hanssen, B.L.; Siraj, S.; Wong, D.K.Y. Recent strategies to minimise fouling in electrochemical detection systems. Rev. Anal. Chem. 2016, 35, 1-28. [CrossRef] 